\title{
From a Literature Review to a Conceptual Framework for Customer-To-Customer Value Co-Creation
}

\author{
Sneha Pandey* \\ Department of Management Studies, Malaviya National Institute of Technology, India \\ Email: pandey.sneha1994@gmail.com \\ Divesh Kumar \\ Department Management Studies, Malaviya National Institute of Technology, India \\ Email: diveshcms@ gmail.com
}

\begin{abstract}
Albeit customer-to-customer interaction (CCI) is something inevitable in a socially dense interaction-rich service setup, there has not been any review in this area of literature. However, a considerable amount of extant research has highlighted the importance of inter-customer encounters during a service encounter. Customer-tocustomer value co-creation during collective consumption is gaining relevance in the field of contemporary services marketing research. This review deals with searching articles through the Scopus database and systematically reviewing 115 articles related to customer-to-customer value co-creation and CCI. While highlighting their contribution to the services marketing literature and various theories, methodologies followed by the authors, it paves the way for developing the proposed conceptual framework for the process of customer-to-customer value co-creation. This way, the article adds up to the extant multi-approach research area revolving around customerto-customer interactions/relationships, customer engagement, and value co-creation among the customers during a service encounter. The study recommends practitioners analyze and monitor the aspects proposed through a practical implication.
\end{abstract}

Keywords: Customer-to-customer interactions, Customer-to-customer value cocreation, Customer engagement, $\mathrm{C} 2 \mathrm{C}$, Value co-creation

\section{INTRODUCTION}

Service marketing is based upon one of the most important theories, i.e., Servicedominant logic (S-D logic), which conceptualizes value as embedded in the interactive process between a customer and the service provider (Rihova et al., 2013). The logic 
proposes 'value-in-use', which implies that value can be realized only after the consumer consumes a product or service. Hence, in service marketing, we infer that value is realized after consumption experience(s) (Vargo, \& Lusch, 2004). Another theoretical contribution by Heinonen et al. (2013) and Heinonen et al. (2010) is Customer-Dominant logic (C-D logic), which emphasized the customer being the center of inquiry. This forms the basis for understanding customer-to-customer value cocreation. "Value can be created not only by interactions between a service provider and customers but also among customer-to-customer interactions" (Heinonen et al., 2018; Kim et al., 2019). 'Customer-to-customer value co-creation' is the co-creation among the customers in a socially dense service setup like golf tournaments, cruise trips, adventure and leisure tours (Rihova et al., 2013).

Although the number of studies directly talking about customer-to-customer value co-creation is very less, the service marketing researchers realized the importance of inter-customer interactions during service encounters long ago. A pivotal study by Martin and Pranter (1989) drew researchers' attention to the importance of intercustomer compatibility in a service environment while highlighting its impact on focal customer satisfaction/dissatisfaction. Since then, the management realized the importance of facilitating positive interpersonal relationships and maintaining compatibility among the customers in service encounters. Harris et al. (1995) studied the impact of inter-customers oral interactions (word-of-mouth or post-evaluation discussion) during a service encounter upon the customer's perceived service quality. This further highlighted their role as 'unpaid human resources' working for the management.

Many researchers empirically showed how the inter-customer relationships or customer-to-customer interaction (either positive or negative) impacted their satisfaction post-visit intensification with the service, content generation (Antón et al., 2018), and customer citizenship behavior (CCB) in the form of helping others and wordof-mouth (WOM) (Kim et al., 2019). However, none of the studies focused on taking up this area for literature review. This would be the first study to pave the way from customer-to-customer interactions to customer-to-customer value co-creation, embedded in the collective consumption of service. Campos et al. (2018) did a review on the co-creation of tourists' experience and identified two basic perspectives on onsite experience co-creation. The first one was destination's (engaging tourists for memorable tourist experience), and the second was of tourists (who actively participate, contribute to some aspects, interact with others, and engage themselves in the on-site tourism experience). Adhikari and Bhattacharya (2016) focused on experiential marketing and examined the antecedents and implications of experience. Group interactions amongst tourists influence their experience consumption (Adhikari, \& 
Bhattacharya, 2016; Martin \& Pranter, 1989; Wu, 2007). In their review, Kandampully et al. (2018) identified customer-to-customer interactions (CCIs) to be important for studying customer experience management (CEM). Such interactions were found inevitable for hospitality experiences where customers consume collectively, for example, music concerts.

However, a common limitation in all these reviews is that none of them completely focus on the fact that customer-to-customer interactions are a way of creating value among the customers, i.e., C2C value co-creation. Moreover, all these focus only upon the tourism industry. In fact, Bharti et al. (2018) talked of various crucial aspects of value co-creation, like customer-to-customer value co-creation, that need exclusive attention.

Braun et al. (2016) came up with the first study to introduce three types of customer-engaging behaviors facilitating value. Out of these, 'customer-to-customer interaction-focused customer engagement' had never been focused upon before. This grabs scholarly attention towards examining the much-needed relationship between customer engagement and $\mathrm{C} 2 \mathrm{C}$ value co-creation.

Rihova et al. (2013) identified customer-to-customer value co-creation to take place in four social layers, namely, "detached customers", "social bubble", "temporary communitas", and "ongoing neo-tribes" while identifying the values customers derive in each layer, separately. Later in 2015, they proposed a methodological and epistemological conceptual framework based upon the interactional theory in parallel with the practice theory. Rihova et al. (2018) identified $18 \mathrm{C} 2 \mathrm{C}$ co-creation practices among five $\mathrm{UK}$ based festival visitors. Out of the five articles focusing directly on $\mathrm{C} 2 \mathrm{C}$ value co-creation, three are by these authors. Hence, they can be identified as a major source of pivotal work in this area of literature. The area clearly needs more attention.

Another observation was that customer-to-customer interactions are an integral part of the $\mathrm{C} 2 \mathrm{C}$ value co-creation literature. This justifies the relevance of including the extant literature on CCIs during service encounters amongst the articles for review. Inter-customer interaction is an effective way of co-creating a service experience (McColl-Kennedy et al., 2012). But only a few studies in the past have been able to identify how various service setups have been able to leverage such interactions in order to enhance their customers' experiences. Considering these shortcomings, the study attempts to review 115 articles from both areas of research. Following Callahan (2014) and Rosado-Serrano et al. (2018) for drawing a roadmap in order to summarize the entire literature, the article structures itself by segregating into $4 \mathrm{Ws}$ (What, Where, Why, and How). It depicts the contemporary issues in the service marketing literature regarding customer-to-customer interactions or inter-customer relationships during service encounters. 
Earlier studies were short-sighted to examine the mere presence of other customers and its impact on the focal customer's satisfaction/dissatisfaction (Martin \& Pranter, 1989). However, lately, the studies have been highlighting the customers' gain or co-creation of value/experiences with each other, thus, enhancing their attachment with service providers indirectly. For instance, Line et al. (2018) observed the impact of the inter-tourist encounters on attachment with the destination, which further intensifies their decision to return to a destination. While presenting the various aspects attached, the review aims at drawing attention towards all of the above critical issues. It moves further by proposing a conceptual framework and suggesting some future directions in this area of literature.

\section{REVIEW DESIGN AND STRUCTURE}

\section{Review Design}

We followed the review of Rosado-Serrano et al. (2018) and searched for published and articles in-press on the Scopus database. This included the articles published by Sage Journals, Web of Science, Science Direct, Springer Link, Taylor and Francis, Emerald and Wiley. The articles were related to customer-to-customer interaction during service encounters and customer-to-customer value co-creation. Our selection of articles was based upon two decisions. First, choosing articles between 1989 and 2019 (last online search done on 30 March 2019). We selected 1989 as the initial year because Martin and Pranter (1989) came up with their pivotal study suggesting the service management personnel as to how they can foster compatibility among the customers, thus impacting their satisfaction or dissatisfaction levels during service encounters. Figure 1 depicts the literature search procedure followed. The keywords selected by the authors on Scopus have been listed in the following table 1. 
Figure 1 Literature Search Procedure

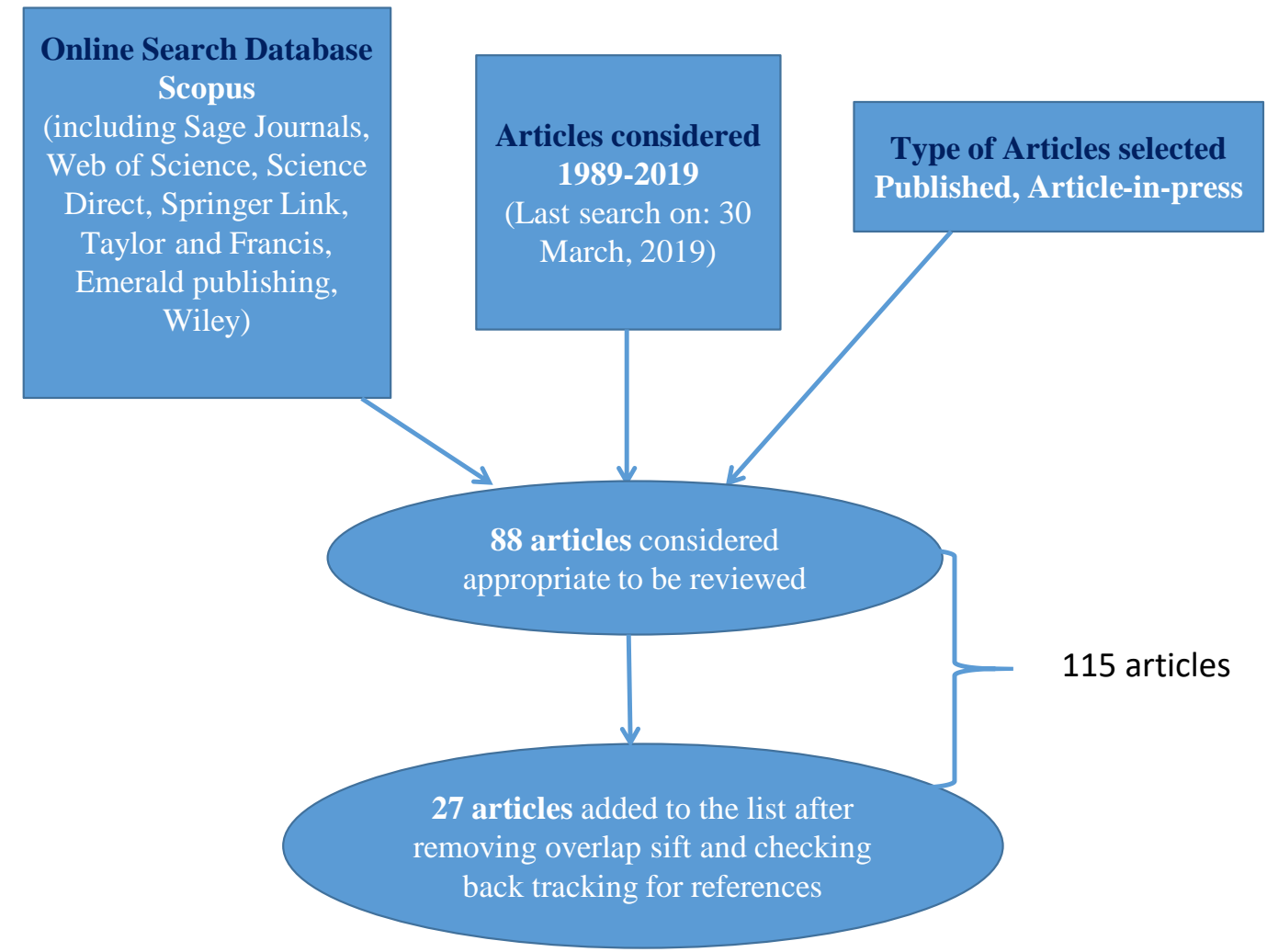


Table 1 Literature Search Terms

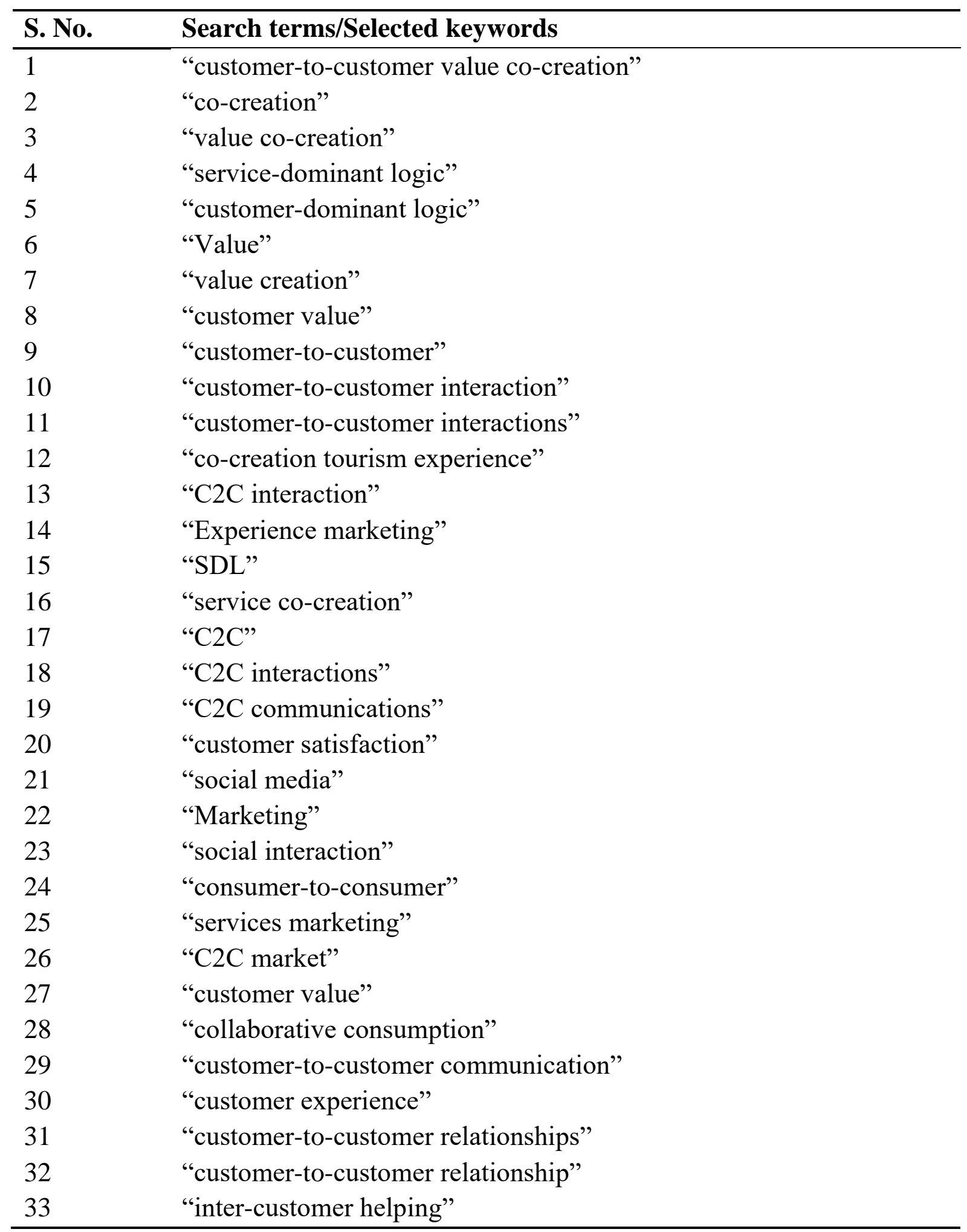

In the following section, we present the structure of this literature review. The method followed in order to identify the articles has been discussed. Later, a comprehensive overview of the inter-customer encounters, interactions, or customer- 
to-customer value co-creation, follows. In the last section, we provide the way for future research.

After removing the overlap sift and checking backtracking for the references, we had 115 articles, out of which the initial Scopus search fetched 88 articles. The rest 27 articles were identified from the "References" section of these articles.

These articles are published in 52 distinct academic journals. The maximum number of articles are published in Journal of Services Marketing, Tourism Management, Journal of Service Research, Journal of Service Management, Journal of Business Research, International Journal of Contemporary Hospitality Management (table 2).

Table 2 Journals

\begin{tabular}{lr}
\hline Row Labels & Count of Source title \\
\hline Annals of Leisure Research & 1 \\
Australasian Marketing Journal & 2 \\
Current Issues in Tourism & 4 \\
European Business Review & 1 \\
European Journal of Marketing & 2 \\
European Sport Management Quarterly & 3 \\
Food Service Technology & 1 \\
Industrial Management and Data Systems & 1 \\
Information Resources Management Journal & 1 \\
International Journal of Asian Business and Information & 1 \\
Management & 1 \\
International Journal of Business Excellence & 9 \\
International Journal of Contemporary Hospitality & \\
Management & 1 \\
International Journal of Electronic Commerce & 2 \\
International Journal of Hospitality Management & 1 \\
International Journal of Retail and Distribution Management & 2 \\
International Journal of Service Industry Management & 2 \\
International Journal of Tourism Research & 1 \\
International Review of Retail, Distribution and Consumer & 1 \\
Research & 1 \\
Internet Research & 1 \\
Journal of Business Economics and Management & 6 \\
Journal of Business Research & 1 \\
Journal of Consumer Marketing & 1 \\
Journal of Consumer Research & 1 \\
Journal of Hospitality and Tourism Research & 1 \\
Journal of Hospitality Marketing and Management & 1 \\
Journal of Marketing Research & \\
Journal of Product Innovation Management & 1 \\
\hline & \\
\hline
\end{tabular}


Table 2 Journals (con.)

\begin{tabular}{lr}
\hline Row Labels & Count of Source title \\
\hline Journal of Research in Interactive Marketing & 1 \\
Journal of Retailing & 1 \\
Journal of Retailing and Consumer Services & 2 \\
Journal of Service Management & 5 \\
Journal of Service Research & 5 \\
Journal of Service Science Research & 1 \\
Journal of Service Theory and Practice & 1 \\
Journal of Services Marketing & 16 \\
Journal of Strategic Marketing & 3 \\
Journal of the Academy of Marketing Science & 2 \\
Journal of Travel and Tourism Marketing & 4 \\
Journal of Travel Research & 1 \\
Management Research News & 1 \\
Managing Service Quality & 1 \\
Marketing Intelligence and Planning & 2 \\
Psychology \& Marketing & 1 \\
Qualitative Market Research & 1 \\
Review of Managerial Science & 1 \\
Service Business & 2 \\
Service Industries Journal & 5 \\
The Journal of Consumer Affairs & 1 \\
Total Quality Management and Business Excellence & 1 \\
Tourism Management & 1 \\
blank) & 4 \\
Grand Total & \\
\hline
\end{tabular}

The following section is inspired by the reviews of Callahan (2014) and RosadoSerrano et al. (2018) in order to answer the 4 Ws (What, Where, How, and Why) of this systematic literature review and provide a desirable structure for them.

\section{Review Structure}

1. What do we already know about customer-to-customer interactions in the service environment?

Section 3 included the previous works of research scholars in the area of $\mathrm{C} 2 \mathrm{C}$ interaction in a service setup and customer-to-customer $(\mathrm{C} 2 \mathrm{C})$ value co-creation. The section, titled 'An Overview', discusses the various dimensions to the research area, in particular.

2. Why do researchers need to know more about $\mathrm{C} 2 \mathrm{C}$ value co-creation stemming from customer-to-customer interactions? 
Although 'customer-to-customer interactions' have been studied for quite some time now, only a few researchers have focussed on how such interactions lead to or facilitate value co-creation among the customers. Various managerial implications from the extant literature highlight the gain of service providers who facilitate customer-tocustomer interactions. This is included in section 4, which is titled "Theoretical Underpinnings". This section highlights various theories upon which the researchers have based their studies.

\section{Industries and methodologies previously used in the area?}

Section 5 includes identifying the various industries in which the selected articles have been taken up. Various research methods undertaken by them have also been highlighted. Section 5.1 and section 5.2 simultaneously highlight the various industries and methodologies followed by these researchers.

\section{How can this review help in filling the gaps in the previous literature and guide future research?}

Section 6, titled 'Research Propositions and Conceptual Model' offers several propositions based upon the literature, thus, paving the way for conceptual model development. The next section is 'Discussion and managerial implications', followed by 'Future Research and Limitations'. In this manner, we aim to answer the question: "How would this systematic literature review fill the gaps in the previous literature and contribute to the literature of $\mathrm{C} 2 \mathrm{C}$ value co-creation?"

\section{AN OVERVIEW}

Lovelock and Young (1979) considered other customers as 'partial employees' for the service-providing organizations (Harris \& Baron, 2004). Martin and Pranter (1989) talked about 'compatibility management' among customers during a service counter. They focused on the need to study customer-customer interactions during such service encounters which require customer proximity (like leisure centers where people play snooker or come to bowl) (Jones, 1995). McGrath and Otnes (1995) studied customer behavior during service encounters and classified the types of strangers in a retail setup. These customers were either classified as 'Overt' (help-seekers, reactive helpers, proactive helpers, admirers, competitors, complainers) or 'Covert' (followers, observers, judge, accused, spoilers). Harris et al. (1995) noticed that inter-customers oral interactions in the form of Word-of-mouth or post-evaluation discussion impacted their service quality perception. The management could then realize the role of a customer as an "unpaid human resource", working for them through their oral interactions. Subsequently, the role of customers in service setup and inter-customer 
relationships started gaining importance. Martin (1996) found consumer-to-consumer relationships to be affecting consumer satisfaction during a service encounter. Martin and Pranter (1989), Grove and Fisk (1997) assessed the positive or negative impacts of other patrons on a customer during a service. Harris et al. (2000) did a review of the research done in Europe and the US regarding the on-site customer interactions in retail settings. Their review is one of the benchmark studies in the field of service marketing management

The following sections classify various dimensions of customer-to-customer interactions as well as customer-to-customer value co-creation studied until now.

\section{Antecedents of customer-customer interactions during a service encounter and customer engagement}

In service settings, facilitating proximity among the customers, inter-customer interactions do take place as they spend a considerable amount of time with each other (Martin \& Pranter, 1989). C-2-C interaction stimuli could be the various individual traits, consumer needs, service employees, service environment (Harris \& Baron, 2004). However, customer engagement stimuli for such interactions could be the risk reduction tendency or their idea of simply enjoying the experience (Harris et al., 2000). The presence of a strong social network of customers in a service setup can be one of the biggest motivations for high level customer-to-customer interactions (Guenzi \& Pelloni, 2004). The various $\mathrm{C} 2 \mathrm{C}$ interaction antecedents can be "social norms/obligation, group dynamics/proxemics, under- or over-provision of information, recognition, shared focus, service breakdown/delay, altruism and selfishness". The presence of the physical environment (or 'servicescape') (Grove \& Fisk, 1997) was identified as one of the stimuli impacting the C2C exchanges. Aubert-Gamet and Cova (1999) categorized such exchanges as 'economic exchanges', 'socioeconomic exchanges' and 'societal exchanges' (Harris et al., 2000). "Information seeking, information sharing, responsible behavior, personal interaction, feedback, advocacy, helping and tolerance were the identified antecedents of customer-customer value co-creation (Yi \& Gong, 2013; Zadeh et al., 2019).

\section{Customer-to-customer interactions enhancing the experience (value co-creation)}

Social community influences the positive experiences among customers during a service encounter, thus leading to value co-creation (Hsu, 2017). According to Kim et al. (2019), the perceived values (economic, social, emotional, and epistemic) stemming from value creation and destruction factors led to customer citizenship behavior (CCB). This not only calls for engagement in activities like positive WOM and helping other customers but also indulges them as promoters working for the service-providing 
organization indirectly. This, in turn, enhances the organization's reputation and facilitates profits. Kim and Choi (2016) analyzed three types of C2C interactions (friend-interaction, neighboring customer-interaction, and audience-interaction quality) and their impact on customer citizenship behavior. According to Martin and Pranter (1989), when consumers interact with each other in close proximity, they share their dissatisfaction with each other. This helps them become more tolerant towards each other and capable of coping with the service failures. In this way, other customers act as quasi-employees or part-time employees to the service provider. Other customers' on-premise gregarious, crude, violent, leisurely, malcontent, inconsiderate, grungy behavior was found to impact the focal customers' satisfaction (Martin, 1996). Kim et al. (2019) identified the positive outcomes of inter-spectator interactions (value cocreation) during a golf tournament, in the form of focal customer's enhanced perceived value (such as economic, social, epistemic, emotional). Lin et al. (2019) identified other customers' roles as 'help-givers' or 'help-takers' to the mobility impaired persons (MIPs), thus leading to social community driven co-creation. Ben Gamra Zinelabidine et al. (2018) found that the off-track tourists generated some 'out of the box' experiences while interacting with other tourists. Antón et al. (2018) found that more inter-visitor interactions among the museum visitors led to enhance their experiential (learning, entertainment, escapism, and aesthetics) value. Value co-creation can occur due to the conversations among customers, provided they are satisfied while exchanging operant or operand resources among each other (Kim et al., 2019).

\section{Customer-to-customer interactions spoiling the experience (value co- destruction)}

Sometimes, customer-customer interactions can lead to negative outcomes. Other customers' annoying demands can lead to ruining the focal customer's experiences. In fact, Lovelock (1994) categorized the nuisance-creating customers as "jaycustomers", while Bitner et al. (1994) called them "problem customers". Cox et al. (1990) termed those who displayed misbehavior with others during service as "deviant consumer behavior". Fullerton and Punj (1993) called it "aberrant consumer behavior", and Harris and Reynolds (2003) named it "dysfunctional customer behavior" (Gursoy et al., 2017). Mkono (2018) highlighted the concerns with trolling on social media (Web 2.0). Such trolls could occur in the form of fake or malicious reviews by other customers or inflammatory, provocative online posts by them. This might create a bad impression about the company in the heads of the customers and lead to value co-destruction for both the service providers and the customers. Kim and Yi (2017) identified the negative consequence of customer-engagement behavior (CEB) in self-service technologies (SSTs) like ATMs, etc. Jung and Yoo (2017) found that the negative customer-to- 
customer interactions not only spoiled the focal customer's experience but also ruined her/his affection with the service-providing firm. Through the literature review, Heinonen et al. (2018) highlighted instances where the experiences of focal customers got negatively impacted because of fellow customers' verbal, physical and contextual misbehavior.

Value co-destruction, as considered by Kim et al. (2019), can occur in a situation when the resources exchanged among each other (by various actors, including other customers or the organization) in the service environment are handled improperly during the interactions. It occurs when the focal customer feels unhappy or gets upset during the other customer's activity during the $\mathrm{C} 2 \mathrm{C}$ interaction between them.

\section{Types of value derived through $\mathrm{C} 2 \mathrm{C}$ interaction}

During the $\mathrm{C} 2 \mathrm{C}$ interactions or engagement, customers were found to have realized various values, also termed as 'perceived value'. Kim et al. (2019) found that value creation and destruction behaviour of other customers during a service encounter lead to focal customers' perceived values such as economic, social, emotional, and epistemic values. Various customer engagement behaviors lead to social, relationship, autonomous, economic, altruistic, and self-fulfillment benefits (Braun et al., 2016). Abdul-Ghani et al. (2019) found that consumer-to-consumer interactions led to various types of experiences with each other, such as functional, emotional, social, epistemic, and a sense of competition. Kim et al. (2019) found the golf spectators experiencing perceived values like economic, social, epistemic, and emotional values due to their interaction with other spectators present. Reichenberger (2017) found the visitors derive values like emotional, entertainment-related, self-actualization (tourists in 'Communitas' level) and entertainment-related, practical and atmospheric values (tourists in 'Social bubble' level) during the inter-tourist encounters. C2C interactions lead to satisfaction among the customers and other value-related outcomes like positive mood, social value, satisfaction, epistemic, functional value (Becker \& Pizzutti, 2017). Heinonen et al. (2018) found the functional, emotional, and social values resulting from customer-to-customer interactions. Yrjölä et al. (2017) identified consumers being concerned about deriving emotional, symbolic, and functional values while purchasing through $\mathrm{C} 2 \mathrm{C}$ e-commerce platforms. The customer's satisfaction and WOM depended upon such values. Kolyperas and Sparks (2018) observed the four benefits fans derive: social, cultural, economic, and utilitarian during value co-creation in a sportscape.

\section{Roles/types of customers in a service setup}

During a service encounter, the customers have been playing important roles in the lives of the focal customer. According to McGrath and Otnes (1995), strangers 
shopping together in a retail store were either classified as 'Overt' (help-seekers, reactive helpers, proactive helpers, admirer, competitors, complainers) or 'Covert' (who followed, observed, judged, accused, spoiled others' presence). Customers can play the roles of 'reactive help seekers', 'proactive help seekers', 'reactive helpers' and 'proactive helpers' to the fellow customers (Parker \& Ward, 2000) or simply become 'help givers' and 'help takers' (Lin et al., 2019). Customers were also found to play crucial roles of 'complainants' as itinerants, help seekers, storytellers, instigators, or the 'repliers' as listeners, helpers, ironists, educators, and helped their fellow customers in service recovery (Xu et al., 2016). Rihova et al. (2018) identified 18 C2C co-creation practices among five UK based festival visitors, which were insulating, territoriality, non-conforming, communicating, sharing, collaborating, acknowledging, advising, conversing, helping, relating, confiding, conforming, trading, initiating, embracing, fun-making and rekindling. Such roles played by the visitors led to $\mathrm{C} 2 \mathrm{C}$ value cocreation.

\section{THEORETICAL UNDERPINNINGS}

In this section, we identified various theories upon which the previous researchers have based their work. It was found that the majority of the articles have been based on service-dominant logic and customer dominant logic. However, the review drew our attention towards other theories like resource exchange and social exchange theories.

\section{Service dominant logic and Customer dominant logic}

S-D logic proposed that a service-providing firm and the customers behave dichotomously during a service encounter. The value can only be generated once the customer uses/avails the service (value-in-use) and not by merely delivering it (Kim et al., 2019; Vargo \& Lusch, 2004). Customers are the co-creators of value during their consumption (Grönroos \& Voima, 2013; Vargo \& Lusch, 2004). Vargo and Lusch (2004, 2008) conceptualize value co-creation to be embedded in the interactive process between the customers and service providers (Xu et al., 2016). S-D logic proposes that value is simply embedded in the customers' experience (Prahalad \& Ramaswamy, 2004), thus, co-created by the customers through their engagement and active participation in interactive activities at the service providing premises (Campos et al., 2018). Kim et al. (2019) and Manh (2018) looked at 'value-in-social-context through the theoretical lens of S-D logic.

Value is embedded in the social environment while consuming within the community. Customer dominant logic (C-D logic) is an extension (Vargo \& Lusch, 2006, 2008) and built upon the S-D logic (Koenig-Lewis et al., 2018). It can be 
differentiated from the service-dominant logic in terms of the shift of interest from exchanging the service between the firm and service provider to the services' impact on the customers' life. It seeks to encompass a "holistic view of the customers' life, practices and experiences", sometimes, even beyond the visible interaction during a service encounter (Medberg \& Heinonen, 2014). Value is co-created from their own perspective (Xu et al., 2016). While exploring C2C co-creation in the tourism industry, Rihova et al. $(2013,2015)$ focused on the practice-based and experiential aspects of the tourists. They suggested marketing firms focus solely on customers and their cocreative social experiences and practices. Customers play a central role in the service delivery and consumption process and are considered the value creators (Ben Gamra Zinelabidine et al., 2018). Rihova et al. (2018) based their study upon the C-D logic and emphasized value that is sprouted among customers within their social spheres and C2C-oriented encounters. Such a form of co-creation occurs when there is resource exchange among customers. Those could be 'operant' (skills, knowledge, capabilities) or operand resources (static or physical things) (Ben Gamra Zinelabidine et al., 2018; Rihova et al., 2018; Vargo \& Lusch, 2008). C-D logic, introduced by Heinonen et al. (2013), plays an important role in $\mathrm{C} 2 \mathrm{C}$ value co-creation and a distinct role in marketing (apart from the S-D logic) (Abdul-Ghani et al., 2019; Rihova et al., 2018).

\section{Other theories}

Through the literature review, several other theories have been identified, which demand attention. The theories like Interpersonal influence theory, Information processing theory, Theory of planned behaviour (Zadeh et al., 2019) Role theory (Parker \& Ward, 2000), Service recovery paradox, Empathy theory (Yi \& Kim, 2017), Social exchange theory (Braun et al., 2016; Kim \& Choi, 2016; Tsai et al., 2017; Yi \& Kim, 2017), Shared reality (Ramanathan \& McGill, 2007), Resource exchange theory (Chan \& Li, 2010; Rosenbaum \& Massiah, 2007), Network theory (Baron \& Harris, 2010; Närvänen et al., 2014), Role theory (Wu, 2008; Yoo et al., 2012), Motivation Opportunity Ability model as antecedents to C2C know-how exchange (Gruen et al., 2006, 2007), Activity theory, Social identity theory, Labelling theory, Age stereotyping theory (Nicholls \& Gad Mohsen, 2015), Social network theory (Curth et al., 2014; Tax et al., 2013), Cognitive Dissonance theory, Commitment theory (Curth et al., 2014), Social Network theory (Black et al., 2014), Self-actualisation and Servuction model (Finsterwalder \& Kuppelwieser, 2011), Social Facilitation theory and Affiliative Conflict theory (Tombs \& McColl-Kennedy, 2010), Cooperation theory, Public space theory, Social psychology theory and Social theory (Nicholls, 2010), Social construction theory (Ji et al., 2018), Attribution theory and Dissonance theory (Raajpoot \& Sharma, 2006), C2C engagement theory (Meshram \& O'Cass, 2018), Rational cost 
theory, rational choice theory (Clauss et al., 2018), Social Facilitation theory (Kim \& Choi, 2016), Social information processing theory and Interpersonal Influence Theory (Yi et al., 2013), Theory of aversive racism and Distinctiveness Theory (Johnson \& Grier, 2013) Uncertainty reduction theory (Adjei et al., 2010), Similarity effect (Brack \& Benkenstein, 2012), Chameleon effect (Kim et al., 2019) and Broaden-and-build theory (Lyubomirsky, 2001).

\section{RESEARCH DONE TILL YET}

\section{Industries in which $\mathrm{C} 2 \mathrm{C}$ related research has been conducted}

The literature review gives a fair idea about the industries in which customer-tocustomer interaction has been examined. Studies have been conducted in the retail industry Martin, 1996; Tomazelli et al., 2017), dining restaurants, small and medium restaurants, mobility-impaired person's (MIPs) online (Lin et al., 2019), cafes (Tombs \& McColl-Kennedy, 2010) where other customers were considered the social influencers, their stay impacted focal customer's experience. It was found that the majority of the work has been done in the tourism industry, like the work by Ben Gamra Zinelabidine et al. (2018), Campos et al. (2016) and Reichenberger (2017).

\section{Methodologies used by previous researchers}

The majority of the studies concerned with $\mathrm{C} 2 \mathrm{C}$ value co-creation were either epistemological conceptual (Rihova et al., 2013, 2015) or qualitative studies (Ben Gamra Zinelabidine et al., 2018; Campos et al., 2016; Chan \& Li, 2010; Rihova et al., 2018; Xu et al., 2016). However, some of them were based upon experimental studies, case studies or observation (Tombs \& McColl-Kennedy, 2010) and ethnographic observations (Kolyperas \& Sparks, 2018). Figure 2 gives a fair view of the methodologies used by previous researchers in this regard. 
Figure 2 Methodologies Used

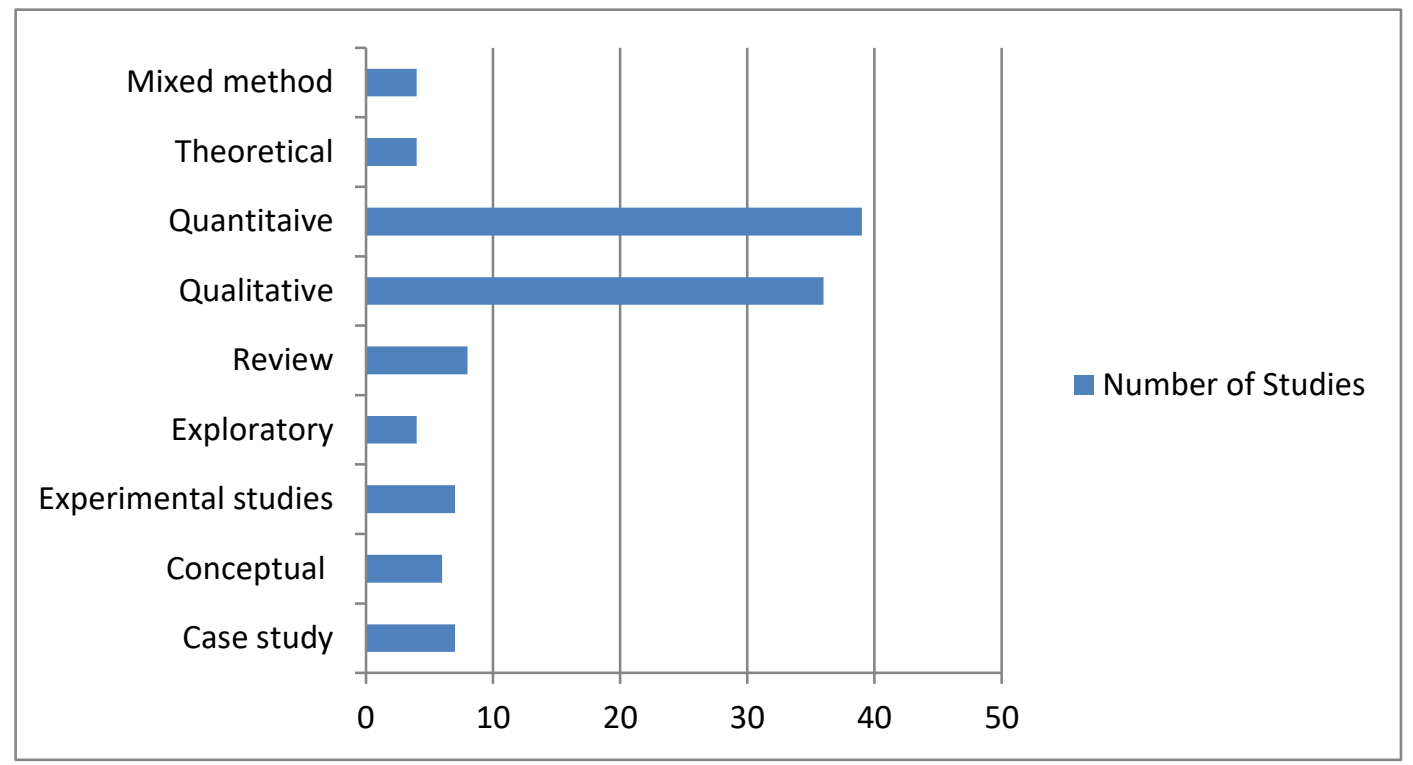

\section{RESEARCH PROPOSITIONS AND CONCEPTUAL MODEL}

The literature has carved the way out for developing the proposed framework (figure 3). We propose that customer-to-customer interactions are leading to customerto-customer value co-creation. The interactions may be positively or negatively impacting the whole value co-creation process.

"There may exist a cycle of consumer engagement, comprised of experiences, value, consumer engagement, and behavioral outcomes that present new experiences" (Abdul-Ghani et al., 2019; Brodie et al., 2011), based upon which we attempt to develop the conceptual framework model (with two-dimensional perspectives, positive and negative co-creation). 
Figure 3 Conceptual framework

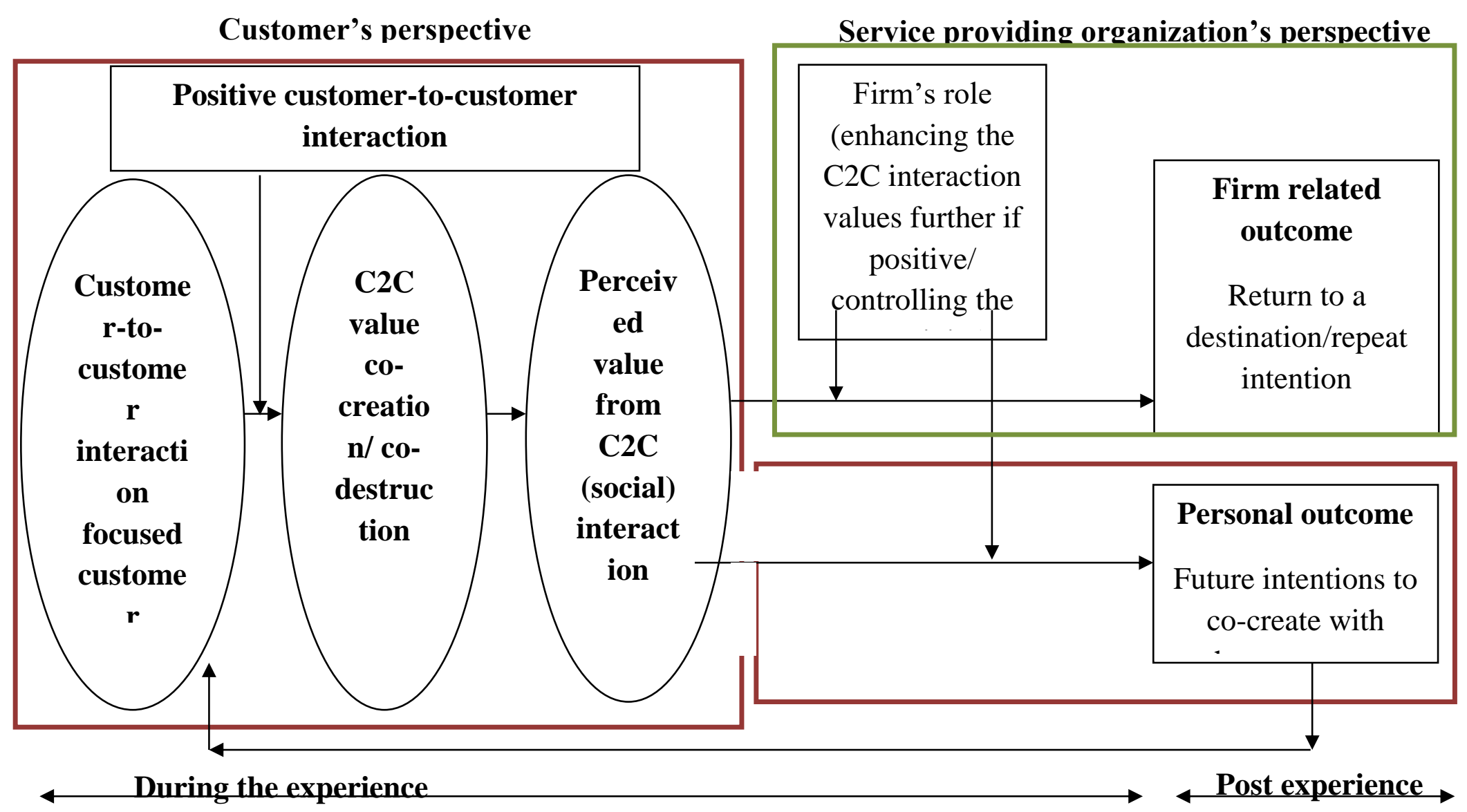


Customer engagement has a wider scope as it includes the voluntary contribution of resources among actors. It is embedded in interactions and is a result of some motivational drivers (Jaakkola \& Alexander, 2014). Customer engagement comprises endeavors displayed by the customers, which might be extrinsically or intrinsically motivated. Since the review focuses on $\mathrm{C} 2 \mathrm{C}$ interactions, the authors tend to focus on CE as customers' motivation behind satisfying their own needs (Gummerus et al., 2012). It was found that personal $\mathrm{C} 2 \mathrm{C}$ exchange relationship does play an integral role in customers' engagement process (Braun et al., 2016). Customer voluntary performance (Rosenbaum \& Massiah, 2007) or C2C interaction-focused engagement (word-ofmouth and experience sharing among customers) benefit the customers in many ways. Such engagement behavior includes extending help to other customers, which might help reap benefits, such as cost savings and financial benefits (Braun et al., 2016). Studies have demonstrated other customers (such as friends and family, and strangers with whom the customers share the same service experience) play the roles of resource integrators in the 'co-creation of value' (Kim et al., 2019) through C2C interactions. Hence, our first baseline proposition is

\section{Proposition 1: Customer-to-customer interaction-focused engagement impacts on C2C value co-creation}

Moore et al. (2005) mention that customer-customer interactions are an essential component of the customer's service experience. However, customer experiences can both be positive and negative. Both, passion and dysfunctional behavior displayed by other customers during a service encounter are considered as the value co-creation and value co-destruction factors (Kim et al., 2019). Customers create value for their fellow customers by displaying enthusiastic behaviors like cheering (Rihova et al., 2018), which might be manifested as their passion (Chen et al., 2013).

Dysfunctional behavior can be understood as verbal or physical activities (violating the acceptable behavioral norms) by fellow customers that might adversely affect the focal customer's consumption behavior. Such misconduct leads to impact the value outcomes (Heinonen et al., 2018). Negative C2C interactions might cause co-destruction of the focal customer's experience (Grönroos \& Voima, 2013; Plé \& Chumpitaz Cáceres, 2010).

Fellow customers' pleasant demeanor might enhance one's consumption experience, whereas any dysfunctional behavior deteriorates the same and can even lead to inter-customer conflicts (Kim et al., 2019). This can be understood as customerssatisfaction destruction (Plé \& Chumpitaz Cáceres, 2010). "C-to-C interactions can be a source of value co-destruction" (Kim et al., 2019), which further declines the perceived value of at least one party (Plé \& Chumpitaz Cáceres, 2010). 
Prior research indicates that value creation results out of the customer-customer exchange which in turn enhances the perceived benefits from service offerings (Gruen et al., 2007; Jung \& Yoo, 2017). Hence, considering the positive C2C interactions and dysfunctional customer behavior is inevitable. Hence, we propose that

Proposition 2: The nature of $\mathrm{C2C}$ interactions (either positive or negative) moderates the relationship between customer-to-customer interaction focused-engagement.

$\mathrm{C} 2 \mathrm{C}$ value co-creation leads to customer perceived value as well as satisfaction, which somehow positively impacts their loyalty toward the firm (Manh, 2018). Social exchange is an antecedent of value co-creation, and perceived value is an effect. Since value is always considered co-created (according to the SD logic), customer-perceived value is an outcome of the co-creation activities (Manh, 2018) and stems out of the social experiences of visitors with each other and the $(\mathrm{C} 2 \mathrm{C})$ co-created experiences (Reichenberger, 2017). Hence, we propose

\section{Proposition 3: C2C value co-creation impacts customer's perceived value.}

Rosenbaum (2008) found that inter-customer support positively impacts perceived cohesion (with other customers), satisfaction with the firm, behavioral intentions and consumers' sense of well-being. As the customer engages at a social and emotional level with other customers, he/she is gaining knowledge and skills, thus increasing the opportunities to co-create value (Vargo \& Lusch, 2004). Therefore, social/emotional inter-customer support should impact the customers' future intentions to participate in the organization. Customers' future intentions to co-create refer to their ability, role clarity and perceived value in future co-creation (Dong et al., 2008; Meuter et al., 2005). Social/ emotional inter-customer support will positively impact one's future intentions to co-create (Black et al., 2014) and significantly enhance perceived value in future co-creation. Thus, we arrive at the proposition

\section{Proposition 4: The perceived value deriving through the $\mathrm{C} 2 \mathrm{C}$ value co-creation positively impacts a customer's future intention to co-create.}

Till now, very little research has focused on linkages between the $\mathrm{C} 2 \mathrm{C}$ interactions and marketing consequences (Levy et al., 2011). A customer would be displaying the repeat purchase intention in customer-to-customer platforms only when he/she is satisfied with the previous interactional experience in a similar setup (Hsu et al., 2014; Wu et al., 2014), which helped him achieve his personal goal (Fang et al., 2016). "Satisfied customers will make repeat purchases, while dissatisfied customers tend to terminate" (Shihab et al., 2018). Also, if the customer attains positive emotional 
feelings through an experience, word-of-mouth referrals are more likely to occur (Ranaweera \& Prabhu, 2003). Satisfactory C2C encounters enhance one's service quality perception, thus influencing their repeat patronage (Pranter \& Martin, 1991), word-of-mouth referrals (Moore et al., 2005), or recommendations to other customers (Gruen et al., 2007). Kim et al. (2019) highlighted the fact that perceived values impact customer citizenship behavior positively. As a result, the customer is more likely to engage in word-of-mouth activities and help others (Tsai et al., 2017). Also, co-creation or resource-integrating activities among customers lead to customer loyalty (Manh, 2018). Hence, we propose

\section{Proposition 5: The perceived value deriving through the $\mathrm{C2C}$ value co-creation positively impacts the repurchase intention of a customer.}

\section{DISCUSSION AND MANAGERIAL IMPLICATIONS}

For decades authors of the extant literature have tried highlighting the relevance of promoting inter-customer interactions in interaction-rich and socially dense service setup. Such interactions must be encouraged as they are an excellent opportunity for customers to realize the importance of participation in various community activities while generating new values for themselves and the firm (Hsu, 2017). There have been many instances from the literature where $\mathrm{C} 2 \mathrm{C}$ interactions have proved useful for the customers and the service providers. Yoo et al. (2012) also focused on the positive aspect of customer-customer interaction during a service encounter. In the following section, the authors have highlighted the same aspect.

\section{Importance of C2C Value Co-Creation \\ For customers}

There have been instances from the literature where customers gain from $\mathrm{C} 2 \mathrm{C}$ value co-creation. Fellow customers during a service encounter do impact a focal customer's satisfaction level (Martin, 1996). In a health club setup, Black et al. (2014) highlighted the two types of inter-customer support: instrumental (content related to the task or practical help, for example, financial help) and social/emotional (companionship). Receiving emotional and social support from other customers during a service encounter leads to voluntary customer performance (Rosenbaum \& Massiah, 2007). Inter-customer connections during a service encounter lead to gaining social/emotional support from each other (Black et al., 2014). Tinson et al. (2017) highlighted the way parents' experience as a fan, their perceived risk related to the fandom influence the socialization among children. According to them, sports fandom (through customer-to-customer interactions) does facilitate social networking, ties, and 
bonds among customers. In fact, according to Hsu (2017), collective or community engagement leads to enhanced self-esteem.

\section{For service providers}

One may choose to interpret consumer-to-consumer dynamics for firms to reduce support costs or simply may regard it as "surplus support" that serves as the training through which consumers learn how to handle the toolkit better (Jeppesen, 2005). Service providers can shift their focus toward building 'linking value' among their customers through facilitating healthy C2C interactions (Chan \& Li, 2010; Cova, 1997). Not just customers but even service providers can create value for themselves by enabling customer-to-customer interactions (Nicholls, 2010). The social engagement among the visitors (due to C-2-C interactions) ultimately leads them to be loyal toward the service-providing firm (Meshram \& O'Cass, 2018). Such an engagement helps the firms earn instrumental support from its customers (Black et al., 2014) and social benefits like positive word of mouth (Koenig-Lewis et al., 2018). C2C interactions can also help in service recovery (Nicholls, 2010). During C2C service recovery, the complainants were found to be playing the roles of Itinerants, help seekers, storytellers, instigators, while the repliers were categorized as listeners, helpers, ironists, educators. This indirectly strengthened the customers' relationship with the firm as well (Xu et al., 2016). Customer citizenship behavior displayed by the customers during a service failure might not be mandatory but can definitely help the service providers in delivering the service smoothly. Customers helping each other during service failure will reduce the number of complaint cases taken directly to the firm and would ultimately save the firm's costs. Inter-customer help during a service encounter increases the customers' loyalty towards the firm indirectly (Gruen et al., 2007; Yi \& Kim, 2017). Firms could undertake marketing strategies that facilitate customers' engagement during collective shopping (co-shopping) (Chan \& Li, 2010). C2C value co-creation leads to customers' perceived value as well as satisfaction. It also impacts their loyalty toward the firm positively (Manh, 2018). However, a firm can also reap beneficiary-centric results such as firm-desired customer efforts and firm-desired customer insights through C2C User Experience Sharing (UES) apart from the physical spaces. UES platform is a great opportunity for firms to facilitate $\mathrm{C} 2 \mathrm{C}$ interactions (Chen et al., 2018). During a self-service technology (SST), it is very common to find $\mathrm{C} 2 \mathrm{C}$ relationships sprouting up. It is not possible for the customers to reach out to the employees every time. Hence, inter-customer interactions are of utmost importance. This is what makes an SST experience different from traditional service encounters by providing them with timely help extended by fellow customers during a service failure (Yi \& Kim, 2017). In fact, Kim (2017) had empirically proven that customers tend to 
feel frustrated and might also experience negative emotions developed such as anger in case of a service failure. But inter-customer interactions there might prove a boon as they help out of a service failure, thus contributing towards customer satisfaction and preventing negative word-of-mouth. Customer citizenship behavior (Rosenbaum \& Massiah, 2007) might be one of the results of customer engagement. It can be in the form of helping others, word-of-mouth (Tsai et al., 2017), or recommending others (Zadeh et al., 2019). It does play a positive role in enhancing the reputation of the firm (Tsai et al., 2017; Yi \& Gong, 2013).

\section{Leveraging CCIs Smartly}

However, Kim and Yi (2017) found that receiving help from other customers during a service encounter can negatively impact an embarrassed customer. Hence, the service provider should cautiously investigate the direction in which the $\mathrm{C} 2 \mathrm{C}$ interactions are going. There might be times when a customer does not appreciate being surrounded by other customers for help and can only be satisfied by the firm, for example, in a service failure situation.

\section{FUTURE RESEARCH AND LIMITATIONS}

This review proposes the importance of inter-customers' role in enhancing a focal customer's experience during a service encounter. The extensive literature explores the path of customer-to-customer interactions till customer-to-customer value co-creation and attempts at developing a conceptual framework thereafter. The authors highlight the importance of customer-to-customer interaction-focused engagement as an antecedent of $\mathrm{C} 2 \mathrm{C}$ value co-creation and perceived value (at an individual level), leading to the outcomes proposed through the framework. This would be the first literature review in the field of customer-to-customer value co-creation.

Since this is a booming area, not much worked upon, we have identified some major gaps. Although Huang and Choi (2019) created with 'Tourist engagement scale' (TES) to measure the value co-creation process among the cruise tourists, while extending the conventional meaning of customer engagement to tourist engagement (happening among various actors, especially among the co-tourists) and Kim et al. (2019) attempted to test C2C value co-creation and co-destruction empirically. No scholarly research has attempted to develop a customer-to-customer value co-creation measurement scale. Moreover, Abdul-Ghani et al. (2019) claim that the customer engagement cycle continues till the value is derived from a consumption experience. Therefore, more studies focused upon this aspect of engagement should be undertaken. They interestingly propose that the 'consumer engagement' aspect is a prerequisite for getting along with this whole process of 'co-creation of value' through interaction with 
other customers (Li et al., 2017; Storbacka et al., 2016). However, we still need more studies empirically examining the fact whether (during-visit) $\mathrm{C} 2 \mathrm{C}$ interaction focused engagement is the prerequisite of $\mathrm{C} 2 \mathrm{C}$ value co-creation, thus, impacting the re-visit intention of a customer as a result of the post-visit service experience for any future engagement. A longitudinal study showing the impact of $\mathrm{C} 2 \mathrm{C}$ interaction-focussed engagement on $\mathrm{C} 2 \mathrm{C}$ value co-creation, showcasing the pre-visit and post-experience must validate the proposed conceptual model.

\section{REFERENCES}

Abdul-Ghani, E., Hyde, K. F., \& Marshall, R. (2019). Conceptualising engagement in a consumer-to-consumer context. Australasian Marketing Journal, 27(1), 2-13. https://doi.org/10.1016/j.ausmj.2018.06.004

Adhikari, A., \& Bhattacharya, S. (2016). Appraisal of literature on customer experience in tourism sector: review and framework. Current Issues in Tourism, 19(4), 296-321. http://dx.doi.org/10.1080/13683500.2015.1082538

Adjei, M. T., Noble, S. M., \& Noble, C. H. (2010). The influence of C2C communications in online brand communities on customer purchase behavior. Journal of the Academy of Marketing Science, 38(5), 634-653. http://dx.doi.org/10.1007/s11747-009-0178-5

Antón, C., Camarero, C., \& Garrido, M. J. (2018). Exploring the experience value of museum visitors as a co-creation process. Current Issues in Tourism, 21(12), 1406-1425. http://dx.doi.org/10.1080/13683500.2017.1373753

Aubert-Gamet, V., \& Cova, B. (1999). Servicescapes: From modern non-places to postmodern common places. Journal of Business Research, 44(1), 37-45. https://doi.org/10.1016/S0148-2963(97)00176-8

Baron, S., \& Harris, K. (2010). Toward an understanding of consumer perspectives on experiences. Journal of Services Marketing, 24(7), 518-531. http://dx.doi.org/10.1108/08876041011081078

Becker, L. C., \& Pizzutti, C. (2017). C2C value creation: Social anxiety and retail environment. Journal of Research in Interactive Marketing, 11(4), 398-415. http://dx:doi.org/10.1108/JRIM-10-2016-0106

Ben Gamra Zinelabidine, B., Touzani, L., Ben Dahmane, N., \& Touzani, M. (2018). How off-track tourists create their own event: A customer-dominant logic perspective. Qualitative Market Research: An International Journal, 21(4), 549566. https://doi.org/10.1108/QMR-01-2017-0037

Bharti, K., Agrawal, R., \& Sharma, V. (2018). Embrace, before it is too late! Prediction of future studies on value co-creation. International Journal of Business Excellence, 14(1), 121-151. http://doi.org/10.1504/IJBEX.2018.088318 
Bitner, M. J., Booms, B. H., \& Mohr, L. A. (1994). Critical Service Encounters: The Employee's Viewpoint. Journal of Marketing, 58(4), 95-106.

https://doi.org/10.1177/002224299405800408

Black, G. H., Vincent, L. H., \& Skinner, S. J. (2014). Customers helping customers: Payoffs for linking customers. Journal of Services Marketing, 28(5), 391-401. http://dx.doi.org/10.1108/JSM-12-2012-0252

Brack, A. D., \& Benkenstein, M. (2012). The effects of overall similarity regarding the customer-to-customer-relationship in a service context. Journal of Retailing and Consumer Services, 19(5), 501-509. http://dx.doi.org/10.1016/j.jretconser.2012.06.006

Braun, C., Batt, V., Bruhn, M., \& Hadwich, K. (2016). Differentiating customer engaging behavior by targeted benefits-an empirical study. Journal of Consumer Marketing, 33(7), 528-538. http://dx.doi.org/10.1108/JCM-02-2016-1711

Brodie, R. J., Hollebeek, L. D., Juric, B., \& Ilic, A. (2011). Customer engagement: conceptual domain, fundamental propositions, and implications for research. Journal of Service Research, 14(3), 252-271. https://doi.org/10.1108/JCM-022016-1711

Callahan, J. L. (2014). Writing literature reviews: A reprise and update. Human Resource Development Review, 13, 271-275. https://doi.org/10.1177/1534484314536705

Campos, A. C., Mendes, J., do Valle, P. O., \& Scott, N. (2016). Co-creation experiences: Attention and memorability. Journal of Travel \& Tourism Marketing, 33(9), 1309-1336. http://dx.doi.org/10.1080/10548408.2015.1118424

Campos, A. C., Mendes, J., Valle, P. O. D., \& Scott, N. (2018). Co-creation of tourist experiences: A literature review. Current Issues in Tourism, 21(4), 369-400. http://dx.doi.org/10.1080/13683500.2015.1081158

Chan, K. W., \& Li, S. Y. (2010). Understanding consumer-to-consumer interactions in virtual communities: The salience of reciprocity. Journal of Business Research, 63(9-10), 1033-1040. http://dx.doi.org/10.1016/j.jbusres.2008.08.009

Chen, C. Y., Lin, Y. H., \& Chiu, H. T. (2013). Development and psychometric evaluation of sport stadium atmosphere scale in spectator sport events. European Sport Management Quarterly, 13, 200-215. https://doi.org/10.1080/16184742.2012.759602

Chen, T., Drennan, J., Andrews, L., \& Hollebeek, L. D. (2018). User experience sharing: Understanding customer initiation of value co-creation in online communities. European Journal of Marketing, 52(5/6), 1154-1184. http://dx.doi.org/10.1108/BIJ-10-2012-0068 
Clauss, T., Harengel, P., \& Hock, M. (2018). The perception of value of platformbased business models in the sharing economy: Determining the drivers of user loyalty. Review of Managerial Science, 1-30. https://link.springer.com/article/10.1007/s11846-018-0313-0

Cova, B. (1997). Community and consumption: towards a definition of the "linking value" of a product or services. European Journal of Marketing, 31(3/4), 297316. https://doi.org/10.1108/03090569710162380

Cox, D., Cox, A. D., \& Moschis, G. P. (1990). When consumer behavior goes bad: an investigation of adolescent shoplifting. Journal of Consumer Research, 17(2), 149-59. https://doi.org/10.1086/208545

Curth, S., Uhrich, S., \& Benkenstein, M. (2014). How commitment to fellow customers affects the customer-firm relationship and customer citizenship behavior. Journal of Services Marketing, 28(2), 147-158. https://doi.org/10.1108/JSM-08-2012-0145

Dong, B., Evans, K. R., \& Zou, S. (2008). The effects of customer participation in cocreated service recovery. Journal of the Academy of Marketing Science, 36(1), 123-137. https://doi.org/10.1007/s11747-007-0059-8

Fang, J., George, B., Shao, Y., \& Wen, C. (2016). Affective and cognitive factors influencing repeat buying in e-commerce. Electronic Commerce Research and Applications, 19, 44-55. https://doi.org/10.1016/j.elerap.2016.08.001

Finsterwalder, J., \& Kuppelwieser, V. G. (2011). Co-creation by engaging beyond oneself: the influence of task contribution on perceived customer-to-customer social interaction during a group service encounter. Journal of Strategic Marketing, 19(7), 607-618. https://doi.org/10.1080/0965254X.2011.599494

Fullerton, R. A., \& Punj, G. (1993). Choosing to misbehave: A structural model of aberrant consumer behavior. Advances in Consumer Research, 20(1), 570-574. https://www.acrwebsite.org/volumes/7515/volumes/v20/NA\%20-\%2020

Grönroos, C., \& Voima, P. (2013). Critical service logic: making sense of value creation and co-creation. Journal of the Academy of Marketing Science, 41(2), 133-150. http://doi.org/10.1007/s11747-012-0308-3

Grove, S. J., \& Fisk, R. P. (1997). The impact of other customers on service experiences: a critical incident examination of "getting along". Journal of Retailing, 73(1), 63-85. https://doi.org/10.1016/S0022-4359(97)90015-4

Gruen, T. W., Osmonbekov, T., \& Czaplewski, A. J. (2006). eWOM: The impact of customer-to-customer online know-how exchange on customer value and loyalty. Journal of Business Research, 59(4), 449-456. https://doi.org/10.1016/j.jbusres.2005.10.004 
Gruen, T. W., Osmonbekov, T., \& Czaplewski, A. J. (2007). Customer-to-customer exchange: Its MOA antecedents and its impact on value creation and loyalty. Journal of the Academy of Marketing Science, 35(4), 537-549. https://doi.org/10.1007/s11747-006-0012-2

Guenzi, P., \& Pelloni, O. (2004). The impact of interpersonal relationships on customer satisfaction and loyalty to the service provider. International Journal of Service Industry Management, 15(4), 365-384. https://doi.org/10.1108/09564230410552059

Gummerus, J., Liljander, V., Weman, E., \& Pihlström, M. (2012). Customer engagement in a Facebook brand community. Management Research Review, 35(9), 857- 877. https://doi.org/10.1108/01409171211256578

Gursoy, D., Cai, R., \& Anaya, G. J. (2017). Developing a typology of disruptive customer behaviors: Influence of customer misbehavior on service experience of by-standing customers. International Journal of Contemporary Hospitality Management, 29(9), 2341-2360. https://doi.org/10.1108/IJCHM-08-2016-0454

Harris, K., \& Baron, S. (2004). Consumer-to-consumer conversations in service settings. Journal of Service Research, 6(3), 287-303. https://doi.org/10.1177/1094670503260132

Harris, K., Baron, S., \& Parker, C. (2000). Understanding the consumer experience: It's' good to talk'. Journal of Marketing Management, 16(1-3), 111-127. https://doi.org/10.1362/026725700785100505

Harris, K., Baron, S., \& Ratcliffe, J. (1995). Customers as oral participants in a service setting. Journal of Services Marketing, 9(4), 64-76. https://doi.org/10.1108/08876049510094504

Harris, L. C., \& Reynolds, K. L. (2003). The consequences of dysfunctional customer behaviour. Journal of Service Research, 6(2), 144-161. https://doi.org/10.1177/1094670503257044

Heinonen, K., Jaakkola, E., \& Neganova, I. (2018). Drivers, types and value outcomes of customer-to-customer interaction: An integrative review and research agenda. Journal of Service Theory and Practice, 28(6), 710-732. https://doi.org/10.1108/JSTP-01-2017-0010

Heinonen, K., Strandvik, T., \& Voima, P. (2013). Customer dominant value formation in service. European Business Review, 25(2), 104-123. https://doi.org/10.1108/10.1108/09555341311302639

Heinonen, K., Strandvik, T., Mickelsson, K. J., Edvardsson, B., Sundström, E., \& Andersson, P. (2010). A customer-dominant logic of service. Journal of Service Management, 21(4), 531-548. 
Hsu, L. C. (2017). Investigating community members' purchase intention on Facebook fan page: From a dualistic perspective of trust relationships. Industrial Management \& Data Systems, 117(5), 766-800. https://doi.org/10.1108/IMDS05-2016-0180

Hsu, M. H., Chang, C. M., Chu, K. K., \& Lee, Y. J. (2014). Determinants of repurchase intention in online group- buying: The perspectives of DeLone \& McLean IS success model and trust. Computers in Human Behavior, 36, 234245. https://doi.org/10.1016/j.chb.2014.03.065

Huang, S., \& Choi, H. S. C. (2019). Developing and validating a multidimensional tourist engagement scale (TES). The Service Industries Journal, 1-29. https://doi.org/10.1080/02642069.2019.1576641

Jaakkola, E., \& Alexander, M. (2014). The Role of Customer Engagement Behavior in Value Co-Creation: A Service System Perspective. Journal of Service Research, 17(3), 247-261. https://doi.org/10.1177/1094670514529187

Jeppesen, L. B. (2005). User toolkits for innovation: Consumers support each other. Journal of Product Innovation Management, 22(4), 347-362. https://doi.org/10.1111/j.0737-6782.2005.00131.x

Ji, M., Wong, I. A., Eves, A., \& Leong, A. M. W. (2018). A multilevel investigation of China's regional economic conditions on co-creation of dining experience and outcomes. International Journal of Contemporary Hospitality Management, 30(4), 2132-2152. https://doi.org/10.1108/IJCHM-08-2016-0474

Johnson, G. D., \& Grier, S. A. (2013). Understanding the influence of cross-cultural consumer-to-consumer interaction on consumer service satisfaction. Journal of Business Research, 66(3), 306-313. https://doi.org/10.1016/j.jbusres.2011.08.010 Jones, P. (1995). Managing customer-customer interactions within the service. Management Research News, 18(12), 54-59. https://doi.org/10.1108/eb028434

Jung, J. H., \& Yoo, J. J. (2017). Customer-to-customer interactions on customer citizenship behavior. Service Business, 11(1), 117-139. https://doi.org/10.1007/s11628-016-0304-7

Kandampully, J., Zhang, T., \& Jaakkola, E. (2018). Customer experience management in hospitality: A literature synthesis, new understanding and research agenda. International Journal of Contemporary Hospitality Management, 30(1), 21-56. https://doi.org/10.1108/IJCHM-10-2015-0549

Kim, H. S., \& Choi, B. (2016). The effects of three customer-to-customer interaction quality types on customer experience quality and citizenship behavior in mass service settings. Journal of Services Marketing, 30(4), 384-397. http://dx.doi.org/10.1108/JSM-06-2014-0194 
Kim, K., Byon, K. K., \& Baek, W. (2019). Customer-to-customer value co-creation and co-destruction in sporting events. The Service Industries Journal, 40(9-10), 1-23. https://doi.org/10.1080/02642069.2019.1586887

Kim, S. Y. (2017). Inter-customer helping during service failures: The mediating role of disappointment. Journal of Service Science Research, 9(1), 61-71. https://doi.org/10.1007/s12927-017-0004-4

Kim, S. Y., \& Yi, Y. (2017). Embarrassed customers: the dark side of receiving help from others. Journal of Service Management, 28(4), 788-806. https://doi.org/10.1108/JOSM-11-2016-0296

Koenig-Lewis, N., Asaad, Y., \& Palmer, A. (2018). Sports events and interaction among spectators: examining antecedents of spectators' value creation. European Sport Management Quarterly, 18(2), 193-215. https://doi.org/10.1080/16184742.2017.136145

Kolyperas, D., \& Sparks, L. (2018). Exploring value co-creation in Fan Fests: the role of fans. Journal of Strategic Marketing, 26(1), 71-84. https://doi.org/10.1080/0965254X.2017.1374298

Levy, S. E., Getz, D., \& Hudson, S. (2011). A field experimental investigation of managerially facilitated consumer-to-consumer interaction. Journal of Travel \& Tourism Marketing, 28(6), 656-674. https://doi.org/10.1080/10548408.2011.603633

Li, L. P., Juric, B., \& Brodie, R. J. (2017). Dynamic multi-actor engagement in networks: the case of United Breaks Guitars. Journal of Service Theory and Practice, 27 (4), 738-760. https://doi.org/10.1108/JSTP-04-2016-0066

Lin, P. M., Peng, K. L., Ren, L., \& Lin, C. W. (2019). Hospitality co-creation with mobility-impaired people. International Journal of Hospitality Management, 77, 492-503. https://doi.org/10.1016/j.ijhm.2018.08.013

Line, N. D., Hanks, L., \& McGinley, S. (2018). When birds flock together: an identification of the destination social servicescape. Journal of Travel \& Tourism Marketing, 35(7), 882-894. https://doi.org/10.1080/10548408.2018.1445065

Lovelock, C. H. (1994). Product plus: How product and service equals competitive advantage, McGraw-Hill.

Lovelock, C., \& Young, R. (1979). Looking to customers to increase productivity. Harvard Business Review, 57, 168-78. https://doi.org/10.1080/10548408.2018.1445065

Lyubomirsky, S. (2001). Why are some people happier than others? The role of cognitive and motivational processes in well-being. American psychologist, 56(3), 239. https://doi.org/10.1037/0003-066X.56.3.239 
Manh, T. N. (2018). Co-creation from consumer resource Integration. International Journal of Asian Business and Information Management, 9(3), 1-13. https://doi.org/10.4018/IJABIM.2018070101

Martin, C. L. (1996). Consumer-to-consumer relationships: Satisfaction with other consumers' public behavior. Journal of Consumer Affairs, 30(1), 146-169. http://www.jstor.com/stable/23859374

Martin, C. L., \& Pranter, C. A. (1989). Compatibility management: Customer-tocustomer relation- ships in service environments. Journal of Services Marketing, 3(3), 5-15. https://doi.org/10.1108/EUM0000000002488

McColl-Kennedy, J. R., Vargo, S. L., Dagger, T. S., Sweeney, J. C., \& Kasteren, Y. V. (2012). Health care customer value co-creation practice styles. Journal of Service Research, 15(4), 370-389. https://doi.org/10.1177/1094670512442806

McGrath, M. A., \& Otnes, C. (1995). Unacquainted influencers: When strangers interact in the retail setting. Journal of Business Research, 32(3), 261-272. https://doi.org/10.1016/0148-2963(94)00051-F

Medberg, G., \& Heinonen, K. (2014). Invisible value formation: A netnography in retail banking. International Journal of Bank Marketing, 32(6), 590-607. https://doi.org/10.1108/IJBM-03-2014-0041

Meshram, K., \& O'Cass, A. (2018). Senior citizens' perspective on the value offerings of third place via customer to customer (C-2-C) engagement. Journal of Services Marketing, 32(2), 175-194. https://doi.org/10.1108/JSM-08-2014-0269

Meuter, M. L., Bitner, M. J., Ostrom, A. L., \& Brown, S. W. (2005). Choosing among alternative service delivery modes: An investigation of customer trial of selfservice technologies. Journal of Marketing, 69(2), 61-83. https://doi.org/10.1509/jmkg.69.2.61.60759

Mkono, M. (2018). 'Troll alert!': Provocation and harassment in tourism and hospitality social media. Current Issues in Tourism, 21(7), 791-804. https://doi.org/10.1080/13683500.2015.1106447

Moore, M., Moore, M. L., \& Capella, M. (2005). The impact of customer-to-customer interactions in a high personal contact service setting. Journal of Services Marketing, 19(7), 482-491. http://dx.doi.org/10.1108/08876040510625981

Närvänen, E., Gummesson, E., \& Kuusela, H. (2014). The collective consumption network. Managing Service Quality, 24(6), 545-564. https://doi.org/10.1108/MSQ-08-2013-0159

Nicholls, R. (2010). New directions for customer-to-customer interaction research. Journal of Services Marketing, 24(1), 87-97. https://doi.org/10.1108/08876041011017916 
Nicholls, R., \& Gad Mohsen, M. (2015). Other customer age: Exploring customer age-difference related CCI. Journal of Services Marketing, 29(4), 255-267. http://dx.doi.org/10.1108/JSM-04-2014-0144

Parker, C., \& Ward, P. (2000). An analysis of role adoptions and scripts during customer-to-customer encounters. European Journal of Marketing, 34(3/4), 341359. http://dx.doi.org/10.1108/03090560010311894

Plé, L., \& Chumpitaz Cáceres, R. (2010). Not always co-creation: Introducing interactional co-destruction of value in service-dominant logic. Journal of Services Marketing, 24, 430-437. http://dx.doi.org/10.1108/08876041011072546

Prahalad, C. K., \& Ramaswamy, V. (2004). The future of competition: Co-creating unique value with customers, Harvard Business School Press.

Pranter, C. A., \& Martin, C. L. (1991). Compatibility management: Roles in service performers. Journal of Services Marketing, 5(2), 43-53. https://doi.org/10.1108/08876049110035530

Raajpoot, N. A., \& Sharma, A. (2006). Perceptions of incompatibility in customer-tocustomer interactions: Examining individual level differences. Journal of Services Marketing, 20(5), 324-332. http://dx.doi.org/10.1108/08876040610679936

Ramanathan, S., \& McGill, A. L. (2007). Consuming with others: Social influences on moment-to-moment and retrospective evaluations of an experience. Journal of Consumer Research, 34(4), 506-524. https://www.jstor.org/stable/10.1086/520074

Ranaweera, C., \& Prabhu, J. (2003). On the relative importance of customer satisfaction and trust as determinants of customer retention and positive word of mouth. Journal of Targeting, Measurement and Analysis for Marketing, 12(1), 82-90. https://doi.org/10.1057/palgrave.jt.5740100

Reichenberger, I. (2017). C2C value co-creation through social interactions in tourism. International Journal of Tourism Research, 19(6), 629-638. http://doi.org/10.1002/jtr.2135

Rihova, I., Buhalis, D., Gouthro, M. B., \& Moital, M. (2018). Customer-to-customer co-creation practices in tourism: Lessons from customer-dominant logic. Tourism Management, 67, 362-375. http://doi.org/10.1016/j.tourman.2018.02.010

Rihova, I., Buhalis, D., Moital, M., \& Gouthro, M. B. (2013). Social layers of customer-to-customer value co-creation. Journal of Service Management, 24(5), 553-566. https://doi.org/10.1108/JOSM-04-2013-0092

Rihova, I., Buhalis, D., Moital, M., \& Gouthro, M. B. (2015). Conceptualising customer-to-customer value co-creation in tourism. International Journal of Tourism Research, 17(4), 356-363. https://doi.org/10.1002/jtr.1993 
Rosado-Serrano, A., Paul, J., \& Dikova, D. (2018). International franchising: A literature review and research agenda. Journal of Business Research, 85, 238257. https://doi.org/10.1016/j.jbusres.2017.12.049

Rosenbaum, M. S. (2008). Return on community for consumers and service establishments. Journal of Service Research, 11(2), 179-196. https://doi.org/10.117/1094670506295851

Rosenbaum, M. S., \& Massiah, C. A. (2007). When customers receive support from other customers: Exploring the influence of inter-customer social support on customer voluntary performance. Journal of Service Research, 9(3), 257-270. https://doi.org/10.1177/1094670506295851

Shihab, M. R., Maulana, D., \& Hidayanto, A. N. (2018). Determinants of Repurchase intention in C2C E-Commerce: Customers' Perspectives of merchants and platform providers. Information Resources Management Journal, 31(3), 54-76. https://doi.org/10.4018/IRMJ.2018070104

Storbacka, K., Brodie, R. J., Bohman, T., Maglio, P. P., \& Nenonen, S. (2016). Actor engagement as a microfoundation for value co-creation. Journal of Business Research, 69, 3008- 3017. http://dx.doi.org/10.1016/j.jbusres.2016.02.034

Tax, S. S., McCutcheon, D., \& Wilkinson, I. F. (2013). The service delivery network (SDN) a customer-centric perspective of the customer journey. Journal of Service Research, 16(4), 454-470. http://dx.doi.org/10.1177/1094670513481108

Tinson, J., Sinclair, G., \& Kolyperas, D. (2017). Sport fandom and parenthood. European Sport Management Quarterly, 17(3), 370-391. https://doi:10.1080/16184742.2017.1280068

Tomazelli, J., Broilo, P. L., Espartel, L. B., \& Basso, K. (2017). The effects of store environment elements on customer-to-customer interactions involving older shoppers. Journal of Services Marketing, 31(4/5), 339-350. https://doi.org/10.1108/JSM-05-2016-0200

Tombs, A. G., \& McColl-Kennedy, J. R. (2010). Social and spatial influence of customers on other customers in the social-servicescape. Australasian Marketing Journal, 18(3), 120-131. https://doi.org/10.1016/j.ausmj.2010.04.001

Tsai, C. Y. D., Wu, S. H., \& Huang, S. C. T. (2017). From mandatory to voluntary: consumer cooperation and citizenship behaviour. The Service Industries Journal, 37(7-8), 521-543. http://dx.doi.org/10.1080/02642069.2017.1337099

Vargo, S. L., \& Lusch, R. F. (2006). Service-dominant logic as a foundation for a general theory. The Service-Dominant Logic of Marketing: Dialog, Debate and Directions, 406-420. 
Vargo, S. L., \& Lusch, R. F. (2008). From goods to service (s): Divergences and convergences of logics. Industrial marketing management, 37(3), 254-259. http://dx.doi.org/10.1016/j.indmarman.2007.07.004

Vargo, S. L., \& Lusch, R. L. (2004). Evolving to a new dominant logic for marketing. Journal of Marketing, 68(1), 1-17. https://doi.org/10.1509/jmkg.68.1.1.24036

Wu, C. H. J. (2007). The impact of customer-to-customer interaction and customer homogeneity on customer satisfaction in tourism service - the service encounter prospective. Tourism Management, 28(6), 1518-1528. https://doi.org/10.1016/j.tourman.2007.02.002

Wu, C. H. J. (2008). The influence of customer-to-customer interactions and role typology on customer reaction. The Service Industries Journal, 28(10), 15011513. https://doi.org/10.1080/02642060802250310

Wu, L. Y., Chen, K. Y., Chen, P. Y., \& Cheng, S. L. (2014). Perceived value, transaction cost, and repurchase- intention in online shopping: A relational exchange perspective. Journal of Business Research, 67(1), 2768-2776. https://doi.org/10.1016/j.jbusres.2012.09.007

Xu, Y., Yap, S. F. C., \& Hyde, K. F. (2016). Who is talking, who is listening? Service recovery through online customer-to-customer interactions. Marketing Intelligence \& Planning, 34(3), 421-443. http://dx.doi.org/10.1108/MIP-032015-0053

Yi, Y., \& Gong, T. (2013). Customer value co-creation behavior: Scale development and validation. Journal of Business Research, 66, 1279-1284. https://doi.org/10.1016/j.jbusres.2012.02.026

Yi, Y., \& Kim, S. Y. (2017). The role of other customers during self-service technology failure. Service Business, 11(4), 695-715. https://doi.org/10.1007/s11628-016-0325-2

Yi, Y., Gong, T., \& Lee, H. (2013). The impact of other customers on customer citizenship behavior. Psychology \& Marketing, 30(4), 341-356. https://doi.org/10.1002/mar.20610

Yoo, J. J., Arnold, T. J., \& Frankwick, G. L. (2012). Effects of positive customer-tocustomer service interaction. Journal of Business Research, 65(9), 1313-1320. https://doi.org/10.1016/j.jbusres.2011.10.028

Yrjölä, M., Rintamäki, T., Saarijärvi, H., \& Joensuu, J. (2017). Consumer-toconsumer e-commerce: outcomes and implications. The International Review of Retail, Distribution and Consumer Research, 27(3), 300-315. www.tandfonline.com/10.1080/09593969.2017.1314864

Zadeh, A. H., Zolfagharian, M., \& Hofacker, C. F. (2019). Customer-customer value co-creation in social media: Conceptualization and antecedents. Journal of 
Strategic Marketing, 27(4), 283-302.

https://doi.org/10.1080/0965254X.2017.1344289

Dr. Sneha Pandey (Corresponding author) currently works as a Ph.D. scholar at the Department of Management Studies, Malaviya National Institute of Technology Jaipur, India, in the area of services marketing, particularly on 'Customer-to-customer value co-creation. Her research interest lies in the topics like value co-creation, majorly in tourism and hospitality and consumer behaviour. She has publications in various conferences and journals like Qualitative Market Research: An International journal.

Dr. Divesh Kumar holds a PhD in Marketing from the Department of Management Studies, Indian Institute of Technology (IIT), Roorkee. Presently, he is working as an assistant professor (marketing) in the Department of Management Studies, Malaviya National Institute of Technology Jaipur, India. His research work is published in various journals of international repute, most of which are ranked and indexed by Australian Business Deans Council (ABDC), Scopus and Social Science Citation Index (Clarivate Analytics). His current research interests include sustainability marketing, green consumer behaviour and value co-creation. He has won the highly commended award "Emerald IAM South Asian Management research fund Award 2013. 